\title{
The Application of Politeness Strategies in English and Chinese Movie Reviews
}

\author{
Yuting $\mathrm{Mu}^{1}$ \\ ${ }^{1}$ Shandong Vocational College of Foreign Affairs Translation, China \\ Correspondence: Yuting Mu, Shandong Vocational College of Foreign Affairs Translation, China. E-mail: \\ yisa21@163.com
}

Received: September 16, 2015 Accepted: November 16, 2015 Online Published: November 30, 2015

doi:10.5539/ijel.v5n6p105 URL: http://dx.doi.org/10.5539/ijel.v5n6p105

\begin{abstract}
As an important part of social life and interpersonal cooperation, politeness is reflected in languages. Movie review is a typical form of writing that reflects people's application of politeness strategies consciously or unconsciously. Under the frame of the politeness strategies theory proposed by Brown and Levinson, this paper presents the differences on positive and negative politeness strategies used between English and Chinese movie reviewers. With the selected five famous movies and ten corresponding movie reviews, including five English and five Chinese reviews, the writer discusses the application of positive and negative politeness strategies. Although the difference on frequency of the application of positive and negative politeness strategies within each group is not obvious, the use of specific strategy is different between Chinese and English reviewers. This research also tries to find out the possible reasons of the differences.
\end{abstract}

Keywords: politeness strategy, English movie review, Chinese movie review, language and culture

\section{Introduction}

When talking about politeness, many people may consider English are more positive, while Chinese are more negative. However, in movie reviews, maybe it is another way around. Using the politeness strategy theory of Brown and Levinson, this research will analyze the application of politeness strategies in ten movie reviews, and try to reveal the differences on positive and negative politeness strategies use between English and Chinese movie reviewers. This paper will also try to give possible reasons behind the differences.

Reviews are chosen from IMDb and Douban, five English movie reviews and five Chinese movie reviews, the ten reviews reviewed on the same five movies. Every review has a high click rate and reviews on famous movies. Five movies are Forrest Gump, Titanic, the Legend of 1900, Se7en, and Infernal Affairs (Mou Gaan Dou).

In this paper, the first part is background information and a brief introduction to the theory. The next part is methodology, followed by results and findings. Discussion is the fourth part. The last section is conclusion. This research will focus on the different use of politeness strategies between English review and Chinese review; both quantitative and qualitative data will be analyzed.

\section{Review of Literature}

Politeness is a complex and important topic in various cultures. Politeness, as a basic part of social life and human cooperation, is reflected in languages. It is also an important issue in social linguistics. However, many linguists have studied politeness in different cultures and they claim that there exists a set of universal politeness strategies across different cultures. "In positive politeness cultures, people seek to maintain other people's face by actively doing things for them and taking the lead in interaction. In negative politeness cultures, people seek to maintain other people's face by keeping out of their way and giving them space." (Pennington, 2013). Among politeness theories, an important and influential one is Brown and Levinson's politeness theory.

Brown and Levinson defined face as "the public self-image that every member wants to claim for himself" (Brown \& Levinson, 1987). And they think face consists of two related aspects: negative face, which is "the basic claim to territories, personal preserves, rights and freedom of action and free from imposition. Positive face, on the other hand, is positive self-image or personality claimed by interactants" (Brown \& Levinson, 1987). 
They developed positive politeness and negative politeness. Positive politeness is oriented toward the positive face and the positive self-image. "Positive politeness is approach-based. It anoints the face of the addressee by indicating that in some respects; speaker wants the hearer's wants. Negative politeness, is oriented mainly toward partially satisfying or redressing hearer's negative face, which basically maintains the hearer's self-determination." (Brown \& Levinson, 1987)

According to Brown and Levinson (1987), the theory includes fifteen positive politeness strategies:

1. Notice, attend to the hearer

2. Exaggerate

3. Intensify interest to hearer

4. Use in-group identity markers

5. Seek agreement

6. Avoid disagreement

7. Presuppose, raise, or assert common ground

8. Joke

9. Assert or presuppose speaker's knowledge of and concern of hearer's wants

10. Offer, promise

11. Be optimistic

12. Include both speaker and hearer in the activity

13. Give or ask for reasons

14. Assume or assert reciprocity

15. Give gifts to hearer

(pp. 103-129)

And ten negative politeness strategies:

1. Be conventionally indirect

2. Question, use hedges

3. Be pessimistic

4. Minimize the imposition

5. Give deference

6. Apologize

7. Impersonalize speaker and hearer

8. State the face threat act as a general rule

9. Nominalize

10. Go on record as incurring a debt, or as not indebting hearer

(pp. 132-211)

Several researches have been done on the application of politeness strategies of across different languages. Leech (2007) found there are quantitative and qualitative differences in the scales influencing the norms of politeness between Chinese and English. And Maier (1992) studied the politeness strategies used by native and non-native English speakers in business letters and found striking differences.

Some researchers also studied politeness strategies application in different types of media such as book reviews. $\mathrm{Wu}$ (2012) conducted a research which involved 30 Chinese book reviews from the periodical Modern Foreign Languages and 30 English reviews from the Language in Society. The result shows that there exist differences in the frequencies of most of the politeness strategies in those book reviews. The researcher found that Chinese reviewers prefer to discuss the value of the book while English reviewers tend to use politeness strategies more directly. Based on Leech's politeness theory, Xu (2013) chose 30 Chinese and 30 English prefaces randomly and found the frequency of politeness strategies used in the prefaces are different. However, the writer also discovered some similarities in the Chinese and English prefaces. 
In the field of movie reviews, there is not much research; Liu (2012) studied the randomly selected 30 English reviews published in the New York Times from 2009 to 2011. With the theory of Brown and Levinson as well as Leech's politeness theory, the researcher studied the English reviews in detail, and the result shows that all the use of politeness strategies has a higher frequency of negative politeness strategies. In addition, five politeness strategies were used more frequently than others: notice, attend to $\mathrm{H}$; exaggerate; intensify interest to $\mathrm{H}$; seek agreement, and avoid disagreement.

When people of different languages using politeness strategies in writing movie reviews, is there any difference? In order to find the differences in the application of those politeness strategies in English and Chinese, this paper chose ten movie reviews and the following part will introduce the research questions and methodology of this research.

\section{Methodology}

Research questions:

1. Which group use politeness strategies more frequently? English or Chinese reviewers?

2. How do reviewers apply politeness strategies? Is there any difference in using politeness strategies between English and Chinese reviewers? What are the differences?

3. What are the possible reasons for these differences?

First, five famous and popular movies are chosen according to their popularity and rank, the five movies are Forrest Gump, Titanic, The Legend of 1900, Se7en, and Infernal Affairs (Mou Gaan Dou). All the movies rank high in the two renowned movie website, IMDb and Douban. The former is an English website, and the latter is a Chinese website. Also I am familiar with the five movies and have seen them before, so I can better analyze the movie reviews.

As for the background of the reviewers, all the selected Chinese reviewers have joined the website for more than five years, and they have written at least five movie reviews on the website. Some of them even wrote more than one hundred reviews and have seen hundreds of movies. On the other side, all the reviewers selected from IMDb have joined the website for at least ten years. And two of them wrote two movie reviews on the website, the other three reviewers wrote more than ten reviews. The reviewers are familiar with the website and movie reviews.

Then, five English movie reviews and five Chinese movie reviews are chosen from the two websites. All the reviews are evaluated as useful and objective, and every review has a high click rate. The length of reviews is about one to one and a half pages.

After that, using two forms (positive politeness strategies and negative politeness strategies), five English and five Chinese reviews are classified according to the fifteen positive politeness strategies and ten negative politeness strategies. When it is in line with two or more strategies, it was categorized into the most obvious and typical one. Finally, the data were analyzed.

\section{Results}

RQ1. The frequency of using politeness strategies

Table 1. Total frequency of politeness strategies in English and Chinese movie reviews

\begin{tabular}{lll}
\hline Politeness strategies & English & Chinese \\
\hline Positive Politeness strategies & $132(68.4 \%)$ & $122(68.5 \%)$ \\
Negative Politeness strategies & $61(31.6 \%)$ & $56(31.5 \%)$ \\
Total & 193 & 178 \\
\hline
\end{tabular}

From the table, we can clearly see the difference in the frequency of using politeness strategies between English and Chinese reviewers. English reviews used positive politeness strategies 132 times $(68.4 \%)$ while Chinese is $122(68.5 \%)$. As for negative politeness strategies, English reviews totally used 61 times $(31.6 \%)$ and the total frequency of Chinese reviews is $56(31.5 \%)$. However, the differences between the application of positive and negative politeness strategies within each group are not obvious.

RQ2. The differences in using politeness strategies between English and Chinese reviewers 
Table 2. Five positive politeness strategies used most frequently in English and Chinese reviews (H stands for hearer, and $\mathrm{S}$ stands for speaker)

\begin{tabular}{lll}
\hline Positive Politeness Strategies & Frequency in English Reviews & Frequency in Chinese Reviews \\
\hline Notice, attend to H & 42 & 29 \\
Exaggerate & 23 & 19 \\
Use in-group identity & 16 & 19 \\
Give gifts & 13 & 13 \\
Include both S and H in the activity & 12 & 12 \\
\hline
\end{tabular}

Five positive politeness strategies that used most frequently by English reviewers are notice to $\mathrm{H}$, exaggerate, use in-group identity, give gifts, and include both $\mathrm{S}$ and $\mathrm{H}$ in the activity. The situation of Chinese reviewers is the same.

Examples and detailed analysis:

Strategy 1: notice or attend to $\mathrm{H}$.

In movie reviews, this strategy is used by paying attention directly to the actors, the plot, the director, and other aspects of the movie.

"Leonardo DiCaprio and Kate Winslet are wonderful."

"The film is wonderfully directed by Robert Zemeckis, the film is his opus and is acted by a great cast on all levels."

The two examples show the reviewers' notice to the performance or interest of the movie.

“《泰坦尼克号》都是当之无愧的个中尧楚, 11 项奥斯卡大奖更是对其有力的肯定。”

("Titanic is absolutely the best one, and eleven Oscar award is a high praise.")

“当被人问及最喜欢的电影时，我可以毫无迟疑地告诉他，无间道。”

("When being asked about favorite movies, I can tell him without hesitation, Infernal Affairs.")

Words such as “个中翅楚” (ge zhong qiao chu) “有力肯定”(you li ken ding) “最喜欢”(zui xi huan) also express the reviewer's notice of the film.

Strategy 2: exaggerate

It is a typical positive politeness strategy used by English and Chinese reviewers. The reviewers often use some exaggerative words or expressions. Here are some examples:

"It is at a time like this I wish I could expand my vocabulary to better articulate the virtues and qualities of such a fine film."

"But from the beginning to the end, for full 2 hours, you can cut the tension with a knife."

“此片于 1997 年 11 月 1 日于北美首映之后, 便以星火燎原之势在世界各地迅速掀起观影狂潮。”

(“After its premiere on November 1, 1997 in North America, like a spark of a prairie fire, it sweeps all over the world.")

“即使是单线直叙的手法依然让整个影片充满着让人欲罢不能的张力! ”

"Even using a single line technique, the whole movie is full of tension that you just cannot stop!"

Expressions such as “expand my vocabulary"“cut the tension with a knife”“星火燎原”(xing huo liao yuan)”欲 罢不能”(yu ba bu neng) are very powerful, and this exaggeration adds a positive effect to the reviews.

Strategy 4: use in-group identity

In movie reviews, this strategy is used by applying some in-group language or dialect to convey in-group membership. This involves some technical terms or specific words about the movie.

"The screws hanging unbelievably out of the ocean. The screams of the doomed after she went down. And that ending that brought even the burliest man in the theater to tears."

"Flashlights barely illuminate the slimy walls of the roach-infested tenement of one victim and the dark bedroom of another. Rain pours down in buckets. Bird's-eye-view shots of downtown show dingy, sooty rooftops and grimy streets."

“啊甘正传优秀之处在于这部电影中包含了了美国 8090 年代的反战诠释, 黑色幽默以及迎合 90 年代反智 情绪高涨代表作。”

("The outstanding point of the Forrest Gump is that the film contains the interpretation of the anti-war thoughts during the 1980s to 1990s, black humor and the anti-intellectual sentiment in the 1990s.")

“这就是天下无贼中黎叔那句著名的诗句所讲的道理“我本将心像明月，奈何明月照沟渠”

("It is the meaning of the famous verse of Uncle Li in the World without Thieves: I want my heart like the moon. But the moon just turned to kennels.") 
These sentences mentioned some plots in the films to shorten the distance between the writer and the reader. Reviewers also used some professional movie terms, such as “flashlight" "bird's-eye-view”, and “反战诠释”(fan zhan quan shi)"黑色幽默”(hei se you mo), which are all in-group language. Referring to slang or line of other movies also has the same effect.

Strategy 15: give gifts

In movie reviews, this strategy is usually used by showing understanding or cooperation.

"However from a lot of the comments I have read about this film, I do not think many got the gist of the message from the author and the film maker."

“And after seeing the film, and hearing Tim Roth's words echoing in my mind, he was absolutely right."

“一想到此，也就不难明白导演詹姆斯·卡梅隆的良苦用心了。”

("When you consider this, it is not hard to understand the intention of the director James Cameron.")

“导演故意安排如此的巧合让啊甘成为一个亿万富翁以至于不必像 rain man 似的让观众体会无聊平凡空洞 的感动, 也就是在爆笑和感动的同时, 并不需要你去考虑事业金钱经济政治, 仅仅需要考虑道德的沦丧 与感情的惯乏。”

("Deliberately, the director arranged this coincidence. He lets Gump became a billionaire so that doesn't have to let the audience feel like a rain man. Also during joking and being moved at the same time, you don't need to consider the economy, politic, and money, only need to consider the moral decay and the lack of emotion.")

These sentences show the reviewers' understand of the director and sympathy towards the characters. I think showing understanding of a film is the best way to praise it.

Strategy 12: include both $\mathrm{S}$ and $\mathrm{H}$ in the activity

First let's see some examples:

"Folks, let's get something straight"

"That being the case maybe we all wish we could be just a little more like that, trying to maintain innate goodness and not the trade-offs we often make as we go down lifes highways."

“我们终日在国家机器里心安理得井然有序的生活着, 相信国家会保护我们的安全、相信法律会保障我们 的权利、相信政府会行使最广泛的民主、相信善有善报恶有恶报有志者事竟成...”

("We all live a order life and feel at ease, believe that the country will protect our security,

believe that the law will protect our rights, believe the government will exercise the most extensive democracy, believe what goes around comes around, believe where there is a will there is a way...")

“我们一度以为可以留住的, 所谓的梦想。”

(“Once we thought that we can hold the so-called dream.")

This strategy is easier to use than the above mentioned strategies, and it is achieved through the application of some typical words. Words such as "we"“our" include both the reader and the reviewer in the same activity, which can better pass the message as well as seek agreement.

Table 3. Five most frequent negative politeness strategies used in English reviews

\begin{tabular}{ll}
\hline Negative Politeness strategies & Frequency in English Reviews \\
\hline Question, hedge & 14 \\
Nominalize & 13 \\
Impersonalize S and H & 12 \\
Minimize the imposition & 10 \\
Be pessimistic & 7 \\
\hline
\end{tabular}

Table 4. Five most frequent negative politeness strategies used in Chinese reviews (FTA stands for face threat act)

\begin{tabular}{ll}
\hline Negative Politeness strategies & Frequency in Chinese Reviews \\
\hline Question, hedge & 20 \\
Nominalize & 9 \\
Be pessimistic & 7 \\
Minimize the imposition & 6 \\
State the FTA as a general rule & 6 \\
\hline
\end{tabular}


Examples and detailed analysis:

Strategy 2: question and hedge

In the ten movie reviews, this strategy is mainly applied by using hedges instead of questions.

"That being the case maybe we all wish we could be just a little more like that, trying to maintain innate goodness and not the trade-offs we often make as we go down lifes highways."

"It seems as though mere moments after the initial credits, that the wonderful storytelling and incredible music combined with stunning visuals almost had me moved to tears."

“觉得似乎让 Dustin Hoffman 饰演啊甘更能诠释这部电影的主题.”

("It seems that let Dustin Hoffman act Gump can better interpret the theme of the movie.")

“也许这是心存公理正义的人对抗那些不公平的最后借口和安慰吧!”

("Maybe this is the last excuse and comfort against those unfair things!")

Reviewers use words such as “maybe"“could be"“seems”“似乎”(si hu)”也许”(ye xu) to express a degree of uncertainty, and try to reserve the directors' negative face. Strategy 3 , being pessimistic is similar to this strategy.

Strategy 9: Nominalize

Nominalization is very common in English reviews. The following is some examples.

"full performance""innate goodness"

"the film's success"“"such an interest"

“本片的另一成功之处”(“another success”)

“鲜明的标签”(“obvious label”)

Nominalization makes the comment more formal and widens the distance. But it has to be aware that nominalization is a feature of English. Sometimes nominalization may not use to express deference.

Strategy 4: minimize the imposition

In movie reviews, reviewers apply this strategy by using some expressions in order to delimit the extent of face threat act and weaken the power of tone.

"And some of the plot surrounding the two lovers comes together a little too neatly."

"Except for one tense pursuit through halls and alleys in pouring rain, as well as the bit of ending action, there is surprisingly little violence."

“我总是心软的人, 见不得主角有一点点的难过和心伤, 所以如果我是导演的话, 大抵会让那个女孩留在 船上, 留在 1900 的身边, 然后王子和公主幸福的生活在一起。”

("I am always softhearted, can not bear character suffers a little bit sad or hurt. So if I was the director, generally will let the girl stay in the ship and together with 1900, and then the prince and the princess live a happy life together.")

“这部电影应该算是对自己一个不小的挑战, 同时也注定有一些事情会被颠覆, 有一些观点会被刷新, 有 一些疑问会被解答......”

("The film might be a big challenge to me, also there are some things will be reversed, some view will be refreshed, some questions will be answered......")

Words such as “a little" “little” “一点点”(yi dian dian) “一些”(yi xie) minimize the imposition, and it is an effective way to express the reviewers' opinions and maintain the directors' negative face at the same time.

Strategy 7: impersonalize $\mathrm{S}$ and $\mathrm{H}$

Sometimes, in order to maintain negative face, reviewers are prone to avoid using proverbs such as I and you.

"It seems as though mere moments after the initial credits, that the wonderful storytelling and incredible music combined with stunning visuals almost had me moved to tears."

"If one looks at life through the Somerset lens, one must admit that John Doe has a valid point."

This strategy is also a typical feature of English. Replacement of I and you by the indefinite "one", and use the structure such as "it seems" "it is obvious that" impersonalize the reviewer.

Strategy 8: state the FTA as a general rule 
By quoting some general rules or proverbs, reviewers can seek evidence and agreement. This strategy is widely adopted by Chinese reviewer. Chinese reviewers may want to pass information that has an educational function to readers.

“不过话说回来, 如果杰克最后没有死, 他与露丝不一定能从此幸福快乐的生活在一起。或者, 纵使能白 头到老, 也未必能永结同心。”

("But then again, if Jack did not die, he and Rose may not live a life together. Even if they can have a lasting relationship, they may not necessarily keep the tied knot.”)

“无论多甜蜜的爱情, 在度过最初的蜜月期之后, 必将回归平淡。”

("No matter how sweet love, after the initial honeymoon period, it will be insipid.")

“除了无话可说你还能怎样呢! 悖论面前人人平等。”

("What else can you say? Everyone is equal before the paradox.")

From the above two forms, it can be seen that when it comes to negative politeness strategies, English reviews use more question, nominalize, impersonalize, minimize the imposition, and be pessimistic. However, instead of impersonalize $\mathrm{S}$ and $\mathrm{H}$; Chinese reviews tend to state FTA as a general rule and they want to seek evidence through this way. Also, the order of using is different between English and Chinese reviews.

In addition, English reviews use more positive politeness strategies like notice, exaggerate and offer than Chinese reviews, while Chinese reviews use more in-group identity markers, jokes, and give more reasons.

When comes to negative politeness strategies, English reviewers try to minimize the imposition, impersonalize $\mathrm{S}$ and $\mathrm{H}$, and nominalize when writing. However, Chinese reviewers use more hedges, apologize more, and try to state the FTA as a general rule.

\section{Discussion}

Many previous researchers (e.g., Maier, 1992; WU, 2012) found English and Chinese people both use politeness strategies frequently in book reviews, business letters and advertisements. And some studies found there are differences between the frequency of politeness strategies used in English and Chinese.

This study found politeness strategies are used more frequently in English than Chinese, both positive and negative.

For positive politeness strategies, English use more direct ways, praise the movie or the cast, and tends to recommend other people to see the film, promise it will not let you down.

But Chinese want to conclude the hearer into the same group, and they want to seek agreement. Chinese reviewers involve their own experience more and give more reasons. An interesting thing is they made more jokes of themselves.

For negative politeness strategies, English reviewers also use politeness strategies more frequently, try to minimize the imposition, impersonalize $\mathrm{S}$ and $\mathrm{H}$. Their reviews are more objective. Chinese reviewers use more hedges, often state general rules, apologize to the directors. Their writing is more subjective, and they are more reserve about their opinions.

There are some possible reasons for these differences. Above all, cultural differences that rooted deeply in the two cultures will not only influence the way people see the movies, but also affect their individual understanding. The highlight of individual and collective is another crucial factor. "Different national cultures have been described in terms of an opposition of individualist (i.e., emphasis on people's uniqueness and personal initiative and achievement) vs. collectivist (i.e., emphasis on people's uniformity or sameness, group achievement, and the feelings of others). It is sometimes said that individualist cultures focus on I whereas collectivist cultures focus on we." (Pennington, 2013) Chinese reviewers want to let the reader join the same group and avoid standing out at the same time. They use many in-group identities more frequently. Different purposes also contribute to the differences. English reviewers may unconsciously want to show off, and they use many original words or expressions. In writing style, English reviewers are more creative.

Chinese reviewers seem not so sure about their ideas. They are not confident of being agreed. Social background and different educational style will also influence their use of politeness strategies. However, Chinese reviewers attach more own experience when reviewing those movies, trying to express their deep inner thought. I think this reflects a change in people's way of thinking. However, English reviewers use more technical terms. They are more confident about their opinion. 
It has to be aware that some differences may caused by language itself. English reviews impersonalize $\mathrm{S}$ and $\mathrm{H}$, while Chinese does not have the homologues sentence structure. Also, English reviewers tend to nominalize when writing, but Chinese do not use that much.

\section{Conclusion}

Under the framework of Brown and Levinson's politeness strategy theory, this research explored the differences in the application of positive and negative politeness strategies in five English and five Chinese movie reviews.

Both quantitative and qualitative differences were found. English reviewers used politeness strategies more frequently than Chinese reviewers. Top five positive politeness strategies used by English and Chinese reviewers are the same. However, as for negative politeness strategies, there are slight differences between English and Chinese reviews. English reviews use more questions, nominalizing, impersonalizing, minimizing the imposition, and being pessimistic. However, instead of impersonalize S and H; Chinese reviews tend to state FTA as a general rule. Also, the order of top five negative politeness strategies is different between English and Chinese reviews.

In addition, English reviews use more positive politeness strategies like notice, exaggerate and offer than Chinese reviews. Chinese reviews use more in-group identity markers, jokes, and give more reasons. When comes to negative politeness strategies, English reviewers try to minimize the imposition, impersonalize S and $\mathrm{H}$, and nominalize when writing. However, Chinese reviewers use more hedges, apologize more, and try to state the FTA as a general rule.

Those differences may be caused by several possible reasons, including three main aspects: cultural differences, different educational style, and different language systems.

\section{Further research}

This study revealed the differences in application of politeness strategies between English and Chinese in writing movie reviews. Also this study provides this universal topic some evidence. Hoping in the future, there will be more researches in this interesting and important field. Further research can focus on the influence of reviewers' different background on their movie review writing. And researchers can also do more research on the related field such as politeness strategies in book reviews, letters, advertisements, lectures and so on. It will be helpful if researchers have access to reviewers or writers.

\section{References}

Brown, P., \& Levinson, S. (1987). Politeness: Some universals in language usage. Cambridge: Cambridge University Press.

Chinese Movie Reviews. Retrieved from http://movie.douban.com/

English Movie Reviews. Retrieved from http://www.imdb.com/

Leech, G. (2007). Politeness: Is there an East-West divide? Journal of Politeness Research 3, 167-206. http://dx.doi.org/10.1515/PR.2007.009

Liu Xue. (2012). Politeness Modes in English Movie Reviews. Southwest Jiaotong University.

Maier, P. (1992). Politeness strategies in business letters by native and non-native English speakers. English for Specific Purposes, 11, 189-205. http://dx.doi.org/10.1016/S0889-4906(05)80009-2

Pennington, M.C. (2013). Language in its social context. Week 5 Notes. City University of Hong Kong. MA course.

WU, C. X.. (2012). A contrastive study on politeness strategies in Chinese-English book reviews. Journal of Yibin University, 12, 65-68.

$\mathrm{Xu}, \mathrm{Y}$. N. (2013). The contrastive study on the use of politeness in Chinese preface and English preface. Overseas English, 3, 251-253. 


\section{Appendix}

\section{1: Forrest Gump, 2: Titanic, 3: The Legend of 1900, 4: Se7en, 5: Infernal Affairs (Mou Gaan Dou)}

Using of positive politeness strategies (English reviews)

\begin{tabular}{|c|c|c|c|c|c|c|}
\hline Positive politeness strategies & 1 & 2 & 3 & 4 & 5 & Total Frequency \\
\hline Notice, attend to H (his interests, wants, needs, goods) & 7 & 12 & 8 & 5 & 10 & 42 \\
\hline Exaggerate (interest, approval, sympathy with $\mathrm{H}$ ) & 1 & 7 & 5 & 2 & 8 & 23 \\
\hline \multicolumn{7}{|l|}{ Intensify interest to $\mathrm{H}$} \\
\hline Use in-group identity markers & 3 & 4 & 2 & 5 & 2 & 16 \\
\hline Seek agreement & 2 & 1 & 1 & & & 4 \\
\hline Avoid disagreement & 1 & 2 & & & & 3 \\
\hline $\begin{array}{l}\text { Presuppose, raise, assert common ground } \\
\text { Joke }\end{array}$ & \multicolumn{5}{|c|}{ Joke } & 8 \\
\hline $\begin{array}{l}\text { Assert or presuppose } \mathrm{S} \text { knowledge of and concern for } \mathrm{H} \\
\text { wants }\end{array}$ & & 1 & 2 & & & 3 \\
\hline Offer, promise & 1 & 2 & 1 & 1 & 3 & 8 \\
\hline \multicolumn{7}{|l|}{ Be optimistic } \\
\hline Include both $\mathrm{S}$ and $\mathrm{H}$ in the activity & 2 & & & 9 & 1 & 12 \\
\hline \multicolumn{7}{|l|}{ Give or ask for reasons } \\
\hline \multicolumn{7}{|l|}{ Assume or assert reciprocity } \\
\hline $\begin{array}{l}\text { Give gifts to H, goods, sympathy, understanding, } \\
\text { cooperation }\end{array}$ & 3 & 3 & 2 & 3 & 2 & 13 \\
\hline Total & 22 & 36 & 21 & 25 & 28 & 132 \\
\hline
\end{tabular}

Using of positive politeness strategies (Chinese reviews)

\begin{tabular}{|c|c|c|c|c|c|c|}
\hline Positive politeness strategies & 1 & 2 & 3 & 4 & 5 & Total \\
\hline $\begin{array}{l}\text { Notice, attend to H ( his interests, wants, needs, } \\
\text { goods) }\end{array}$ & 3 & 8 & 5 & 8 & 5 & 29 \\
\hline $\begin{array}{l}\text { Exaggerate( interest, approval, sympathy with } \mathrm{H} \text { ) } \\
\text { Intensify interest to } \mathrm{H}\end{array}$ & 3 & 5 & 4 & 5 & 2 & 19 \\
\hline Use in-group identity markers & 2 & 6 & 3 & 4 & 4 & 19 \\
\hline Seek agreement & & 2 & & 2 & 2 & 6 \\
\hline Avoid disagreement & 1 & & & 1 & & 2 \\
\hline Presuppose, raise, assert common ground & 2 & & 2 & 1 & 1 & 6 \\
\hline Joke & 3 & & 1 & & & 4 \\
\hline $\begin{array}{l}\text { Assert or presuppose } \mathrm{S} \text { knowledge of and concern } \\
\text { for } \mathrm{H} \text { wants }\end{array}$ & & 1 & 1 & & & 2 \\
\hline Offer, promise & 1 & 1 & & & & 2 \\
\hline \multicolumn{7}{|l|}{ Be optimistic } \\
\hline Include both $\mathrm{S}$ and $\mathrm{H}$ in the activity & & & & 5 & 7 & 12 \\
\hline Give or ask for reasons & 1 & 2 & 2 & 1 & 2 & 8 \\
\hline Assume or assert reciprocity & & & & & & \\
\hline $\begin{array}{l}\text { Give gifts to H, goods, sympathy, understanding, } \\
\text { cooperation }\end{array}$ & 2 & 2 & 3 & 2 & 4 & 13 \\
\hline Total & 18 & 27 & 21 & 29 & 27 & 122 \\
\hline
\end{tabular}

Using of negative politeness strategies (English reviews)

\begin{tabular}{|c|c|c|c|c|c|c|}
\hline Politeness strategies & 1 & 2 & 3 & 4 & 5 & Total \\
\hline \multicolumn{7}{|l|}{ Be conventionally indirect } \\
\hline Question, hedge & 3 & 2 & 3 & 2 & 4 & 14 \\
\hline Be pessimistic & 1 & 1 & 3 & 1 & 1 & 7 \\
\hline Minimize the imposition, $\mathrm{Rx}$ & 2 & 3 & 1 & 3 & 1 & 10 \\
\hline \multicolumn{7}{|l|}{ Give deference } \\
\hline Apologize & 1 & & & & & 1 \\
\hline Impersonalize $\mathrm{S}$ and $\mathrm{H}$ & 4 & & 2 & 3 & 3 & 12 \\
\hline State the FTA as a general rule & 1 & 1 & & 1 & 1 & 4 \\
\hline Nominalize & 3 & 2 & 2 & 3 & 3 & 13 \\
\hline \multicolumn{7}{|c|}{$\begin{array}{l}\text { Go on record as incurring a debt, or as not } \\
\text { indebting } \mathrm{H}\end{array}$} \\
\hline Total & 14 & 9 & 11 & 13 & 13 & 61 \\
\hline
\end{tabular}


Using of negative politeness strategies (Chinese reviews)

\begin{tabular}{|c|c|c|c|c|c|c|}
\hline Politeness strategies & 1 & 2 & 3 & 4 & 5 & Total \\
\hline \multicolumn{7}{|l|}{ Be conventionally indirect } \\
\hline Question, hedge & 3 & 3 & 4 & 4 & 6 & 20 \\
\hline Be pessimistic & 1 & 2 & 1 & 2 & 1 & 7 \\
\hline Minimize the imposition, $\mathrm{Rx}$ & & & 2 & 3 & 1 & 6 \\
\hline Give deference & 1 & & & & & 1 \\
\hline Apologize & 1 & & 1 & & & 2 \\
\hline Impersonalize $\mathrm{S}$ and $\mathrm{H}$ & 3 & & & 2 & & 5 \\
\hline State the FTA as a general rule & 1 & 2 & 1 & 1 & 1 & 6 \\
\hline Nominalize & 1 & 2 & & 3 & 3 & 9 \\
\hline \multicolumn{7}{|c|}{$\begin{array}{l}\text { Go on record as incurring a debt, or as not } \\
\text { indebting } \mathrm{H}\end{array}$} \\
\hline Total & 11 & 9 & 9 & 15 & 12 & 56 \\
\hline
\end{tabular}

\section{Copyrights}

Copyright for this article is retained by the author(s), with first publication rights granted to the journal.

This is an open-access article distributed under the terms and conditions of the Creative Commons Attribution license (http://creativecommons.org/licenses/by/3.0/). 